\title{
UROD wt Allele
}

National Cancer Institute

\section{Source}

National Cancer Institute. UROD wt Allele. NCI Thesaurus. Code C95568.

Human UROD wild-type allele is located in the vicinity of $1 \mathrm{p} 34$ and is approximately $4 \mathrm{~kb}$ in length. This allele, which encodes uroporphyrinogen decarboxylase protein, plays a role in the regulation of heme biosynthesis. Mutation of the gene is associated with both familial porphyria cutanea tarda and hepatoerythropoietic porphyria. 